\title{
Mechanism of 5-Fluorouracil-Induced Apoptosis on Cultured Corneal Endothelial Cells
}

\author{
Show-Jen Hong1, Wen-Chuan $\mathrm{Wu}^{2,3}$, Yu-Hung Lai ${ }^{2,3}$, Kwou-Yeung $\mathrm{Wu}^{2,3 *}$ \\ ${ }^{1}$ Department of Pharmacology, College of Medicine, Kaohsiung Medical University, Kaohsiung, Taiwan \\ ${ }^{2}$ Department of Ophthalmology, College of Medicine, Kaohsiung Medical University, Kaohsiung, Taiwan \\ ${ }^{3}$ Department of Ophthalmology, Kaohsiung Medical University Hospital, Kaohsiung, Taiwan \\ Email: ${ }^{*}$ kwye.wu@msa.hinet.net
}

Received 14 January 2014; revised 23 February 2014; accepted 1 March 2014

Copyright (C) 2014 by authors and Scientific Research Publishing Inc.

This work is licensed under the Creative Commons Attribution International License (CC BY). http://creativecommons.org/licenses/by/4.0/

(c) (i) Open Access

\begin{abstract}
Repeated subconjunctival injections with 5-fluorouacil (5-FU) after trabeculectomy are widely used in glaucoma patients for the inhibition of excess scar formation in wound site. The aim of this study was to evaluate the toxic effects of 5-FU and mechanisms of drug-induced apoptosis in cultured porcine corneal endothelial cells. Cellular damage and the caspase pathway were estimated with a MTT assay. The apoptotic characteristics were detected with flow cytometry, a TUNEL test and Western blotting. The results indicated that 5-FU was toxic to corneal endothelial cells in a time- and dose-dependent manner. Pretreatment with a general caspase inhibitor, Z-VAD-FMK, a caspase-8 inhibitor, Z-IETD-FMK, and a caspase-9 inhibitor, Z-LEHD-FMK, reversed 5-FU-induced cellular damage. Following exposure to 5-FU, a flow cytometric assay with MitoLight dye demonstrated the loss of mitochondrial membrane potential. A positive TUNEL test revealed that cellular DNA apoptosis occurred following exposure to $0.05,0.1$, and $0.5 \mathrm{mg} / \mathrm{ml} 5$-FU for $15 \mathrm{~h}$. Annexin V-FITC and negative propidium iodide (PI) staining indicated that the cell membrane underwent apoptosis upon exposure to 0.1 and $0.5 \mathrm{mg} / \mathrm{ml} 5-\mathrm{FU}$ for $15 \mathrm{~h}$. The Western blot assay demonstrated up-regulation of the Bax, p53 and p21 proteins induced by 5-FU. Taken together, these data reveal that 5-FU-induced cellular apoptosis in corneal endothelial cells may be mediated through caspase-8, caspase-9 and mitochondrial regulated pathways, as well as by up-regulation of Bax-, p53-, and p21-dependent signal transduction pathways.
\end{abstract}

\section{Keywordss}

5-Fluorouacil, Corneal Endothelial Cells, Apoptosis

\footnotetext{
${ }^{*}$ Corresponding author.
} 


\section{Introduction}

5-Fluorouracil (5-FU) is a pyrimidine analogue used to treat a wide range of solid tumors [1]. It is frequently used in ophthalmology as an adjuvant in the treatment of various ocular diseases such as pterygium [2] and glaucoma [3] to improve the success of clinical therapy. In glaucoma surgery, 5-FU was introduced as an adjunct agent administered by repeated subconjunctival injections after trabeculectomy to inhibit the proliferation of fibroblasts [4] [5]. Some glaucoma patients may need to receive subconjunctival injections of 5-FU up to a total dose of $65 \mathrm{mg}$, until a desirable reduction in signs of bleb failure appears [6]. When 5-FU is administered repeatedly with subconjunctival injections, a certain amount of the drug may penetrate into the anterior chamber, where it causes toxicity to corneal endothelial cells. Recent evidences showed that 5-FU may induce cellular apoptosis in Tenon's fibroblasts [7]. In cases of the 5-FU accidentally penetrating into the anterior chamber of the eye, the drug may damage corneal endothelial cells and impair physiological functions such as the pumping activity in the corneal endothelium. In a rabbit model, evidence was presented that $5-\mathrm{FU}(50 \mathrm{mg} / \mathrm{ml})$ injected at the trabeculectomy site every five days for 15 days had the deleterious effects on corneal endothelial cells based on observations with confocal microscopy and scanning electron microscopy [8].

Corneal endothelial cells are known to play a crucial role in maintaining corneal transparency. Corneal clarity requires net movement of fluid from the corneal stroma to the aqueous humor [9], and the efficiency of this flux depends on the presence of undamaged corneal endothelial cells and adequate cellular density. Any factor that damages the endothelium cell function may also reduce the efficiency of the corneal pump and therefore affect transparency of cornea [10].

5-FU is widely used as a chemotherapeutic agent because of its capacity to induce apoptosis in malignant cells [11]. Subconjunctival 5-FU injections administered after glaucoma surgery led to apoptotic cell death in the conjunctival epithelium [12]. Thus, the exposure of corneal endothelial cells to specific dosage of 5-FU may induce cellular apoptosis. To date, a limited number of studies have addressed the apoptotic effect of 5-FU on corneal endothelial cells. Apoptosis is a process of natural cell death, which is characterized by extreme heterogeneity of signal transduction pathways. It leads to DNA degradation, the cell membrane damage, mitochondrial dysfunction, and the several degenerative pathways [13] [14]. To evaluate the potential chronic toxicity of 5-FU, cultured porcine corneal endothelial cells were used in the present study to investigate the apoptotic characteristics and mechanism involved in corneal damage induced by 5-FU.

\section{Materials and Methods}

\subsection{Materials}

Cell culture materials including trypsin, minimal essential medium (MEM), glutamine, gentamicin and fetal bovine serum were obtained from GIBCO (Grand Island, NY, USA). MTT (3-[4,5-dimethylthiazol-2-yl]-2,5-diphenyl tetrazolium bromide) and 5-FU were purchased from Sigma Chemical (St. Louis, MO, USA). The general caspase inhibitor, Z-VAD-FMK, caspase-8 inhibitor, Z-IETD-FMK, caspase-9 inhibitor, Z-LEHD-FMK, and a TUNEL apoptosis detection kit were purchased from Calbiochem (Bad Soden, Germany). A MitoLight mitochondrial apoptosis detection kit was purchased from Chemicon International, Inc. (Temecula, CA, USA). Annexin V-FITC plus propidium iodide (PI) double staining kit was purchased from Invitrogen (Carlsbad, CA, USA). The Bax, p53 mouse antibodies and p21 rabbit antibody were purchased from Millipore (Billerica, MA, USA). Western blot Chemiluminescence Reagent Plus was purchased from New England Nuclear (Du Pont, Boston, MA, USA). Protein assay dye and agents used for electrophoresis were purchased from Bio-Rad (Richmond, CA, USA). Horseradish peroxidase-conjugated sheep anti-mouse IgG and donkey anti-rabbit IgG were obtained from Amersham Pharmacia (Buckinghamshire, England). All other chemicals were obtained from Merck (Darmstadt, Germany).

\subsection{Culture of Porcine Corneal Endothelial Cells}

Culture of porcine corneal endothelial cells was performed as published previously [15]. Briefly, porcine eyeballs were collected from a local slaughterhouse. Under sterile conditions, the corneal endothelial cells were separated using $0.25 \%$ trypsin for $30 \mathrm{~min}$. The action of trypsin was stopped by adding minimal essential medium (MEM) containing 10\% fetal bovine serum, $3.8 \mathrm{mM}$ L-glutamine, and $50 \mu \mathrm{g} / \mathrm{ml}$ gentamicin. After centrifugation, the cells were resuspended in a culture flask. The culture was kept in a humidified chamber of $5 \%$ 
$\mathrm{CO}_{2}$ at $37^{\circ} \mathrm{C}$ and the medium was changed every 2 to 3 days.

\subsection{Assay of Cell Viability with MTT}

Cell viability was measured with MTT dye following previously published procedures [16]. The MTT assay is based on the production of purple formazan from a methyltetrazolium salt by the mitochondrial enzymes of viable cells. Cultured cells at a concentration of 4000 cells/well were seeded in 96-well culture plates and allowed to form a monolayer for $24 \mathrm{~h}$. The cells were then exposed to $150 \mu \mathrm{l}$ of serum-free MEM medium containing various concentrations of 5-FU for diverse period of time. Control cells were treated with phosphate-buffered saline (PBS). For analysis of apoptotic caspase pathways, cells were preincubated with different caspase inhibitors including a general caspase inhibitor (Z-VAD-FMK), a caspase-8 inhibitor (Z-IETD-FMK) or a caspase-9 inhibitor (Z-LEHD-FMK) for 1 hour prior to addition of $1 \mathrm{mg} / \mathrm{ml}$ 5-FU for $15 \mathrm{~h}$. After exposure to the drug for $24 \mathrm{~h}$, cells were washed twice with phosphate-buffered saline (PBS) and incubated with $150 \mu \mathrm{l}$ MTT solution $\left(0.833 \mathrm{mg} / \mathrm{ml}\right.$ in PBS) for $4 \mathrm{~h}$ at $37^{\circ} \mathrm{C}$. At the end of the incubation period, MTT solution was carefully aspirated, taking care not to disturb the crystal of purple formazan at the bottom of each well. The formazan reaction product was dissolved by the addition of $150 \mu \mathrm{l}$ dimethyl sulfoxide (DMSO) and the optical density of the fluid in each well was read at $510 \mathrm{~nm}$ in a multi-well spectrophotometer (Titertek Multiscan, Flow Lab, Scotland, UK). Cytotoxicity was calculated based on a significant difference in the optical density between the 5-FUtreated and control groups.

\subsection{Flow Cytometry Assay of Apoptotic Changes in the Cell Membrane and Mitochondrial Membrane Potential}

Apoptosis in the cell membrane was identified by flow cytometry with annexin-V-FITC/PI double staining. Mitochondrial membrane potential changes were assayed with MitoLight dye. In the absence or presence of various concentrations of 5-FU, cells were incubated with $1 \mu \mathrm{g} / \mathrm{ml}$ annexin V-FITC and PI for $10 \mathrm{~min}$, or with $50 \mu \mathrm{l}$ of pre-diluted Mitolight solution (900 $\mu \mathrm{l}$ of water, $1 \mu \mathrm{l}$ of Mitolight dye and $100 \mu \mathrm{l}$ of 10X incubation buffer) for $15 \mathrm{~min}$, following the manufacturer's instructions. Cells were then analyzed by flow cytometry (Becton, Dickinson and Company) for a cell count of 10000.

\subsection{Apoptotic TUNEL Staining on DNA}

Immunohistochemical evidence for DNA strand breaks was obtained using terminal deoxyribonucleotidyltransferase-(TdT)-mediated deoxyuridine-5'-triphosphate-digoxigenin (dUTP) nick-end labeling (TUNEL) assay. The cells were plated on coverslips for at least $24 \mathrm{~h}$ for attachment and then incubated with various concentrations of 5-FU at $37^{\circ} \mathrm{C}$. After exposure to 5-FU, the cells were washed twice with TBS (20 mM Tris-HCl, 140 $\mathrm{mM} \mathrm{NaCl}, \mathrm{pH}$ 7.6). According to the manufacturer's instruction, the monolayer of cells was fixed for 20 min in $4 \%$ formaldehyde at room temperature and then washed three times in TBS. Cell membrane permeability was increased by treating the samples with $20 \mu \mathrm{g} / \mathrm{ml}$ proteinase $\mathrm{K}$ solution at room temperature for 5 minutes. Endogenous peroxidase activity was quenched by immersing the specimens in $2 \% \mathrm{H}_{2} \mathrm{O}_{2}$ at room temperature for 5 minutes. The samples were rinsed by replacing the hydrogen peroxide solution with labeling buffer and reaction mixture solution. The specimens were then placed in a humidified incubator for $1 \mathrm{~h}$ at $37^{\circ} \mathrm{C}$. The labeling reaction was stopped by immersion in stop buffer at room temperature for 5 minutes. The specimens were subsequently washed in TBS. Then, $100 \mu \mathrm{l}$ of streptavidin-horseradish peroxidase was applied to the cells for $20 \mathrm{~min}$ at room temperature. After washing with TBS, the specimens were immersed in diaminobenzidine (DAB) solution at room temperature for $5-10$ min until a satisfactory color reaction was achieved. This assay was validated with the control slides which had been ascertained to contain apoptotic (positive control) and non-apoptotic (negative control) cells.

\subsection{Western Blot Assay of Proteins Involved in Apoptosis}

The Bax, p53 and p21 proteins were detected by sodium dodecyl sulfate-polyacrylamide gel electrophoresis (SDS-PAGE) following previously published procedures [17]. Briefly, cells were treated with 5-FU and washed with $10 \mathrm{ml}$ of buffer A (20 mM N-2-hydroxyethyl-1-piperazine-N'-2-ethanesulfonic acid (HEPES), $1 \mathrm{mM}$ ethylene diamine tetraacetic acid (EDTA), $2 \mu \mathrm{g} / \mathrm{ml}$ aprotinin, $2 \mu \mathrm{g} / \mathrm{ml}$ leupeptin, $1 \mu \mathrm{g} / \mathrm{ml}$ pepstatin A, $\mathrm{pH}$ 7.4). Cells 
were then scraped into ice-cold buffer A and immediately homogenized. Protein concentrations were determined with Bio-Rad protein assay dye. The ten micrograms amount of protein from each sample was added to SDSPAGE sample buffer and heated in a boiling water bath for 5 min. An aliquot was then subjected to 10\% SDSPAGE. The proteins separated by SDS-PAGE were transferred in a Bio-Rad Transblot cell onto nitrocellulose membranes. Transfer was performed at $100 \mathrm{~V}$ for 2 hours in a buffer containing $25 \mathrm{mM}$ Tris- $\mathrm{HCl}, 190 \mathrm{mM}$ glycine, $0.01 \%$ SDS, and 20\% methanol. The blots were blocked at room temperature for 1 hour with buffer solution (20 mM Tris-HCI, $137 \mathrm{mM} \mathrm{NaCl,} \mathrm{pH} \mathrm{7.6)} \mathrm{containing} \mathrm{5 \%} \mathrm{nonfat} \mathrm{milk} \mathrm{and} 0.1 \%$ Tween 20. Incubation was then performed for $1 \mathrm{~h}$ at $37^{\circ} \mathrm{C}$ with monoclonal anti-Bax (1:50), anti-p53 (1:500) or rabbit anti-p21 (1:250) antibodies. The nitrocellulose membrane was washed three times with the same buffer used during the blocking phase and incubated with horseradish peroxidase-conjugated sheep anti-mouse IgG (1:2000) or donkey antirabbit (1:10000) as secondary antibody at room temperature for $1 \mathrm{~h}$. After washing, immunocomplexes were visualized by adding Western blot Chemiluminescence Reagent Plus. The molecular size of the immunoreactive bands was determined by comparison with a set of molecular weight marker proteins (Bio-Rad). Relative band intensity was then analyzed using the LabWorks software 4.6 from UVP Bioimaging systems (Upland, CA, USA).

\subsection{Statistical Analysis}

Data were analyzed by one way ANOVA followed by Dunnett's post hoc analysis. The values were expressed as means \pm standard deviation (SD). All data were significantly different from the corresponding control or 5-FU-only treated group at $p<0.05$.

\section{Results}

\subsection{Effects of 5-FU on Cell Viability and Apoptotic Caspase Pathways}

The MTT assay was used as a marker of cell viability. The mechanism of 5-FU-induced apoptosis in corneal endothelial cells was investigated using cultured porcine cells. Treatment with 5-FU not only decreased cell viability but also induced apoptosis. After incubation with 5-FU for 2, 4, 15, and 24 h, the cell viability was significantly decreased in a time- and dose-dependent manner at concentrations ranging from 0.05, 0.1, 0.5, and 1 $\mathrm{mg} / \mathrm{ml}$ to $5 \mathrm{mg} / \mathrm{ml}$ (Figure $\mathbf{1}(\mathbf{A})$ ).

\subsection{Effects of 5-FU on Apoptotic Caspase Pathways}

To investigate the role of caspases in 5-FU-induced apoptosis, the cells were pretreated with various caspase inhibitors for one hour and then incubated with $1 \mathrm{mg} / \mathrm{ml} \mathrm{5-FU} \mathrm{for} 15 \mathrm{~h}$. After application of the caspase inhibitors, the cellular MTT values were significantly increased in comparison with the 5-FU-only group. Compared with the corresponding control group, the 5-FU-only cells had lower MTT values (as shown in Figure 1(B), Figure 1(C) and Figure 1(D)). The addition of caspase-8, general caspase and caspase-9 inhibitors (Z-IETD-FMK, Z-VAD-FMK, and Z-LEHD-FMK, respectively) at $10^{-5}$ and $10^{-6} \mathrm{M}$ reversed the 5-FU-induced cellular damage.

\subsection{Assay of Mitochondrial Membrane Potential Change after 5-FU Exposure}

Disruption of the mitochondrial transmembrane potential is one of the earliest intracellular changes induced by apoptosis. In healthy cells, Mitolight dye accumulates in the mitochondria and yields red fluorescence. In apoptotic cells, where the mitochondrial membrane potential has been depolarized, the dye aggregates in the cytoplasm and emits green fluorescence, allowing discrimination of apoptotic and nonapoptotic cells. The red color area of control cells, indicate normal mitochondrial membrane potential. Following exposure to $0.05 \mathrm{mg} / \mathrm{ml}$ 5-FU for $15 \mathrm{~h}$ indicated with the black color, as well as the green and blue color lines of the cells treated with $0.1 \mathrm{mg} / \mathrm{ml}$ and $0.5 \mathrm{mg} / \mathrm{ml} \mathrm{5-FU,} \mathrm{respectively} \mathrm{(Figure} \mathrm{2(A)),} \mathrm{the} \mathrm{fluorescence} \mathrm{of} \mathrm{the} \mathrm{MitoLight} \mathrm{dye} \mathrm{in} \mathrm{the} \mathrm{cells}$ showed an obvious change, with red fluorescence in the mitochondria and green in the cytoplasm, as detected by the shift in the relative fluorescence intensity in Figure 2(B). The percentage of MitoLight that accumulated in the mitochondria of the control $(100.3 \% \pm 1.7 \%)$ decreased to $53.4 \% \pm 0.6 \%$ at $0.05 \mathrm{mg} / \mathrm{ml}, 18.8 \% \pm 0.4 \%$ at $0.1 \mathrm{mg} / \mathrm{ml}$, and $10.9 \% \pm 0.5 \%$ at $0.5 \mathrm{mg} / \mathrm{ml}$, respectively (Figure 2(B)). The percentage of MitoLight increased in the cytoplasm from $2.4 \% \pm 0.2 \%$ in the control to $49.3 \% \pm 0.5 \%$ at $0.05 \mathrm{mg} / \mathrm{ml}, 19.2 \% \pm 0.5 \%$ at $0.1 \mathrm{mg} / \mathrm{ml}$, and $9.1 \% \pm 0.4 \%$ at $0.5 \mathrm{mg} / \mathrm{ml}$ (Figure $2(\mathrm{~B})$ ). 


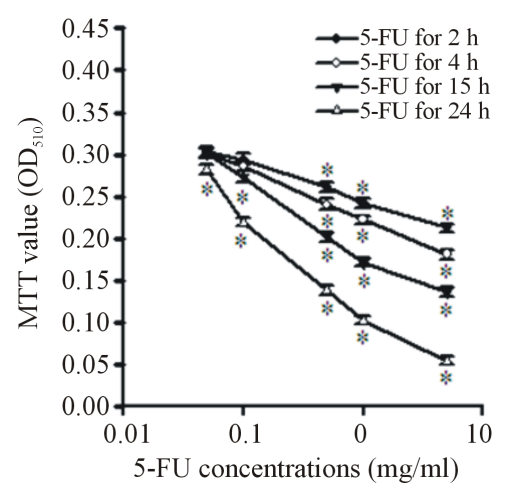

(A)

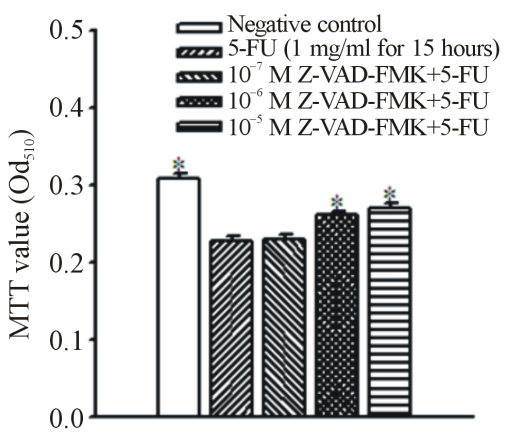

Treatments

(C)

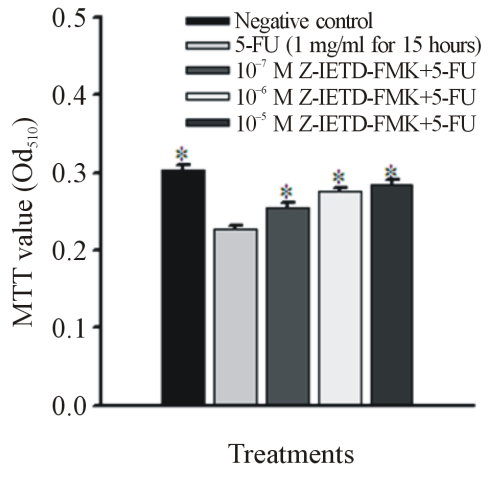

(B)

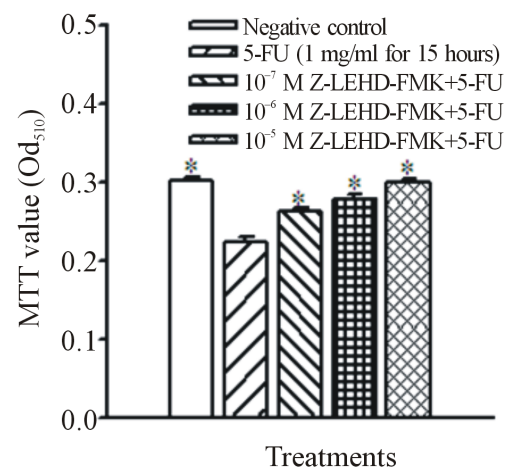

(D)

Figure 1. Effects of 5-FU on cell viability and apoptotic caspase pathways. (A) Cell viability was measured following exposure of cultured porcine corneal endothelial cells to various concentrations of 5-FU at $2,4,15$, and $24 \mathrm{~h}$. The cells were pretreated with (B) a caspase-8 inhibitor, Z-IETD-FMK, (C) a general caspase inhibitor, ZVAD-FMK, or (D) a caspase-9 inhibitor, Z-LEHD-FMK for $1 \mathrm{~h}$ and then exposed to $1 \mathrm{mg} / \mathrm{ml} \mathrm{5-FU}$ for $15 \mathrm{~h}$. The data are presented as means \pm S.D. from six replicates and three independent experiments. ${ }^{*} p<0.05$ compared with experimental control group in A and with 5-FU-only treated group in B, C, and D.

\subsection{Apoptotic TUNEL Staining}

Apoptosis was characterized by TUNEL staining. Morphological evidence of apoptotic cells are characterized by chromatin condensation in the nucleus after treatment with 5-FU. No DNA fragmentation was detected in the PBS-treated negative control after $15 \mathrm{~h}$ (Figure 3(A)). In comparison to the negative staining in the control Figure 3(A), the cells exposed to $0.1 \mathrm{mg} / \mathrm{ml}$ 5-FU for $15 \mathrm{~h}$ was contained sparse cellular condensed chromatin, which was limited to nuclear membrane (Figure 3(B)). Figure 3(C) shows that the cells treated with $0.5 \mathrm{mg} / \mathrm{ml}$ 5-FU exhibit more apoptotic characteristics. The 5-FU induced apoptosis in a dose-dependent manner, and a decrease in viable cell number correlated with an increase in the percentage of apoptosis. Following exposure to 5 $\mathrm{mg} / \mathrm{ml}$ for $15 \mathrm{~h}$, almost all the cells showed typical apoptotic characteristics. Nevertheless, the shape and the content of the cells (cytosol, condensed chromatin and organelles) could still be discriminated (Figure 3(D)).

\subsection{Annexin-PI Staining of Cell Membrane with Flow Cytometry}

To identify the apoptotic effect of 5-FU on cell membrane, annexin V-FITC and PI double staining of cells were performed, and the stained cells were examined with a flow cytometry. The results suggested that appeared to have less of an apoptotic effect on the cell membrane than on cellular organelles, such as mitochondria and DNA of nucleus, in corneal endothelial cells. In the nonapoptotic viable control cells, the annexin V-FITC and PI negative stained cells are located in the bottom left quadrant of the dots (Figure 4(A)). After exposure of cells to 0.1 and $0.5 \mathrm{mg} / \mathrm{ml} 5$-FU for $15 \mathrm{~h}$, a significant proportion of cells $(3.70 \% \pm 0.04 \%$ and $6.36 \% \pm 0.05 \%$, 


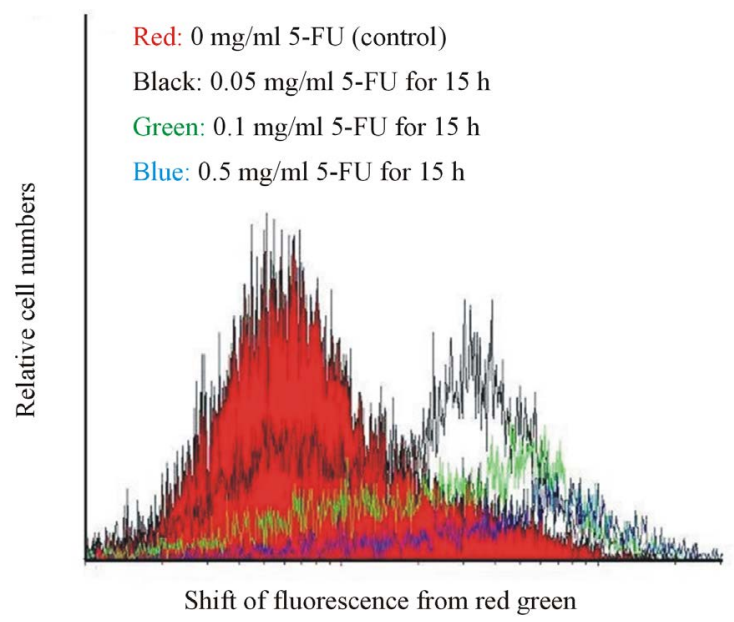

(A)

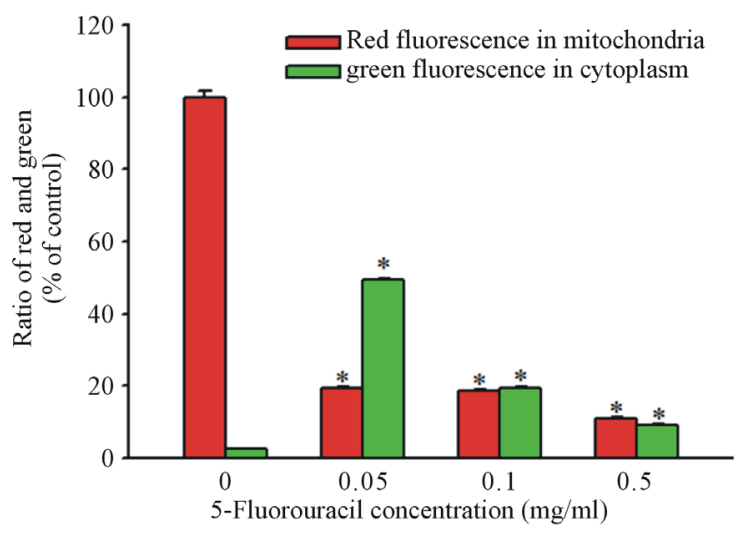

(B)

\begin{abstract}
Figure 2. Flow cytometry assay of mitochondrial membrane potential changes with MitoLight dye in cultured porcine corneal endothelial cells in the presence of 0.05 , 0.1 and $0.5 \mathrm{mg} / \mathrm{ml} \mathrm{5-FU} \mathrm{for} 15 \mathrm{~h}$. (A) The curves represent fluorescing changes in the absence (control, red color) or presence of 0.05 (black color), 0.1 (green color) and 0.5 (blue color) mg/ml 5-FU. (B) The histogram displayed the ratio of red fluorescence in the mitochondria and green fluorescence in the cytoplasm at different concentrations of 5-FU. The asterisk denotes that $p<0.05$ when comparing the red and the green fluorescences with the negative control group. Two other independent experiments produced similar results.
\end{abstract}

respectively, compared to the control of $1.01 \% \pm 0.04 \%$ ) showed positive annexin V-FITC and negative PI staining, depicted by the significant increase in the dot numbers in the bottom right quadrant (Figure 4(B), Figure $4(\mathrm{C})$ ). The cells at this stage of apoptosis were still viable. Following exposure to $5 \mathrm{mg} / \mathrm{ml}$ of 5 FU for $15 \mathrm{~h}$, the PI positive stained cells (upper left quadrant) increased significantly compared to the control $(0.48 \% \pm$ $0.03 \%$ in the control vs. $7.42 \% \pm 0.05 \%$ after $15 \mathrm{~h}$ ) (Figure $4(\mathrm{D})$ ). The cells positively stained with annexin V-FITC and PI (upper right quadrant) increased from 34.24\% $\pm 0.05 \%$ (control) to 37.94\% $\pm 0.04 \%$ after 5 $\mathrm{mg} / \mathrm{ml}$ of $5 \mathrm{FU}$ for $15 \mathrm{~h}$, indicating that the cells were no more viable (Figure 4(D)).

\title{
3.6. Immunoblot Analysis of Proteins Involved in Apoptosis
}

To investigate the effect of 5-FU on proteins involved in apoptosis in the cultured corneal endothelial cells, we 


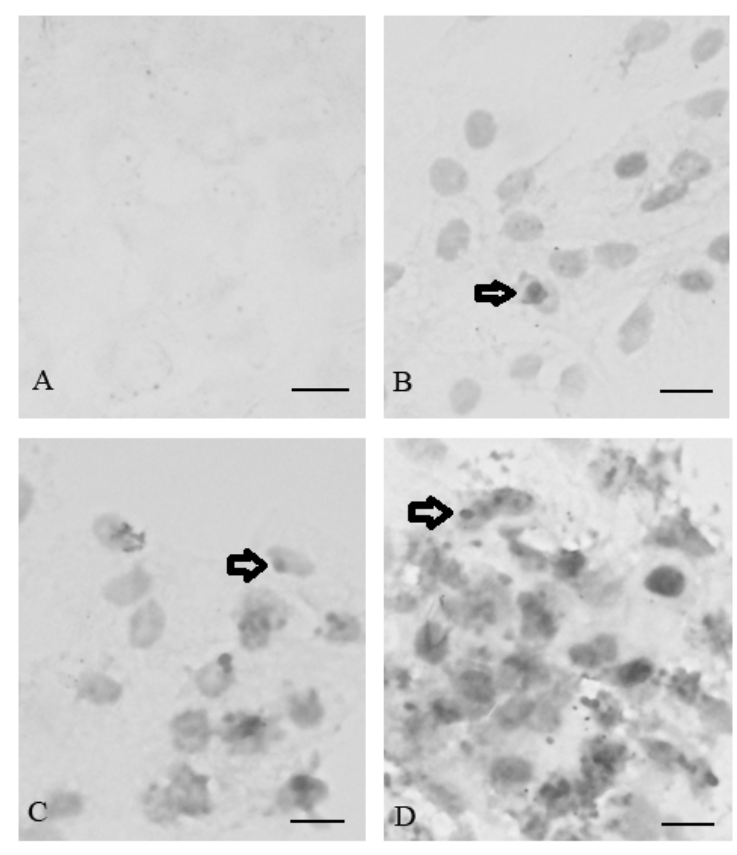

Figure 3. Apoptotic DNA characteristics of corneal endothelial cells visualized with TUNEL staining. (A) The cells were incubated in the absence of 5 -FU or in the presence of (B) 0.1, (C) 0.5 and (D) $5 \mathrm{mg} / \mathrm{ml} \mathrm{5-FU} \mathrm{for} 15$ h. The arrows indicate that positive DNA apoptosis following exposure to 5-FU. The bar represents $3 \mu \mathrm{M}$. Two other independent experiments produced similar results.

examined the apoptotic proteins of Bax, p53, and p21 by Western blotting. The results of three independent experiments demonstrated that 5-FU significantly increased the amount of Bax, p53, and p21 proteins in a dosedependent manner (Figure 5). Densitometric analysis of Bax protein bands showed that the optical density of the proteins in control, and the 5-FU-treated cells was $33 \pm 2$ (control), $47 \pm 3(0.1 \mathrm{mg} / \mathrm{ml}$ 5-FU), $56 \pm 2$ (0.5 $\mathrm{mg} / \mathrm{ml}$ 5-FU), and $96 \pm 3$ (5 mg/ml 5-FU), respectively. In comparison with the control cells (100\% $\pm 6 \%$ ), the optical density for Bax in the 5-FU-treated cells increased to $142 \% \pm 9 \%$ with $0.1 \mathrm{mg} / \mathrm{ml}$ exposure, $170 \% \pm 6 \%$ with $0.5 \mathrm{mg} / \mathrm{ml}$ exposure, and $290 \% \pm 9 \%$ with $5 \mathrm{mg} / \mathrm{ml}$ exposure. The optical density for the p21 proteins was $76 \pm 2$ (control), $136 \pm 2(0.1 \mathrm{mg} / \mathrm{ml}$ 5-FU), $193 \pm 3(0.5 \mathrm{mg} / \mathrm{ml} 5-\mathrm{FU})$ and $270 \pm 2$ (5 mg/ml 5-FU), which corresponded to an increase of $179 \% \pm 3 \%$ for $0.1 \mathrm{mg} / \mathrm{ml}, 254 \% \pm 3 \%$ for $0.5 \mathrm{mg} / \mathrm{ml}$ and $355 \% \pm 4 \%$ for $5 \mathrm{mg} / \mathrm{ml}$, respectively, compared with the control values of $100 \% \pm 3 \%$. In the presence of $0.1,0.5$, and $5 \mathrm{mg} / \mathrm{ml} 5-\mathrm{FU}$ for $15 \mathrm{~h}$, the optical density of the p53 proteins was $60 \pm 3$ (control), $68 \pm 2(0.1 \mathrm{mg} / \mathrm{ml} 5-\mathrm{FU}), 72 \pm 2(0.5 \mathrm{mg} / \mathrm{ml}$ 5-FU), and $193 \pm 3$ (5 mg/ml 5-FU), which corresponded to an increase of $113 \% \pm 5 \%$ for $0.1 \mathrm{mg} / \mathrm{ml}, 120 \% \pm$ $3 \%$ for $0.5 \mathrm{mg} / \mathrm{ml}$ and $322 \% \pm 3 \%$ for $5 \mathrm{mg} / \mathrm{ml}$, respectively, compared with the control value of $100 \% \pm 5 \%$. The data are representative of the average from three independent experiments.

\section{Discussion}

The present study shows that the 5-FU treatment not only decreased cell viability but also induced apoptosis. In the corneal endothelial cells, the apoptotic characteristics of 5-FU were found with partial turnover of cell membrane phosphatidylserine, DNA degradation, destruction of the mitochondrial membrane potential, and up-regulation of Bax, p21, and p53 proteins and caspases-8 and -9.

In cancer cells, 5-FU inhibited cell growth and induced apoptosis, which was accompanied by changes in mitochondria and activity of caspase-9 [18]. 5-FU is commonly used in glaucoma trabeculectomy surgery. Glaucoma patients may receive total doses of subconjunctival 5-FU injections between 2 and $65 \mathrm{mg}$ [6] [19]. A certain amount of 5-FU may penetrate or flow into the ocular anterior chamber from the trabeculectomy site, where it causes apoptosis of corneal endothelial cells. 


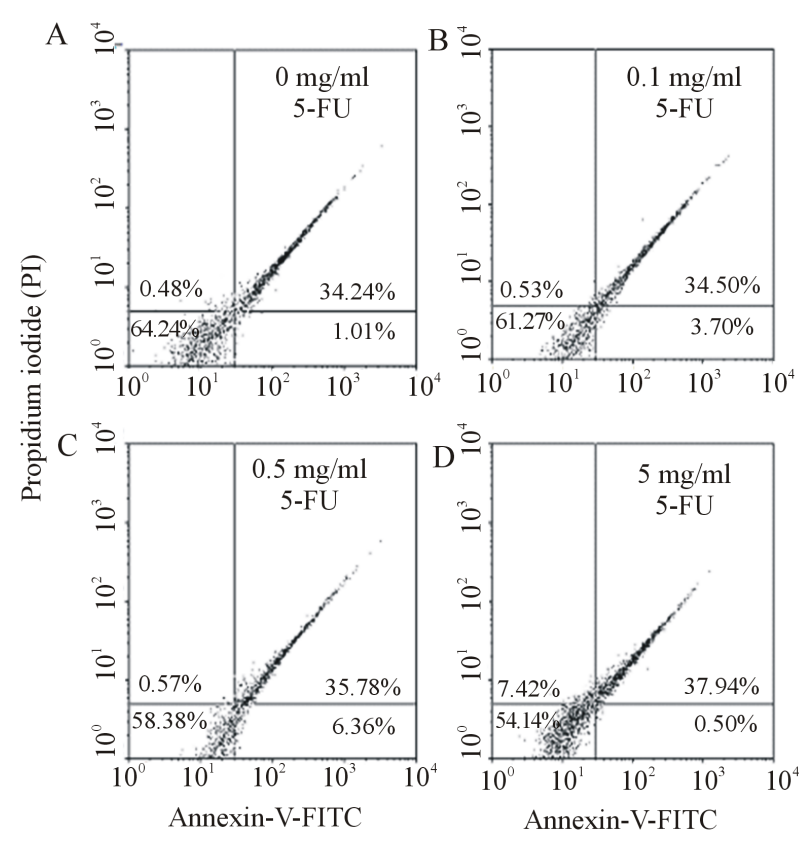

Figure 4. Flow cytometry analysis of cell membranes with annexin V-FITC and PI double staining. (A) The cells were incubated in the absence of 5-FU (control) or the presence of (B) 0.1 , (C) 0.5 , and (D) $5 \mathrm{mg} / \mathrm{ml} \mathrm{5-FU} \mathrm{for} 15 \mathrm{~h}$. Undamaged cells are presented in the bottom left quadrant. After incubation with 0.1 and $0.5 \mathrm{mg} / \mathrm{ml} 5-\mathrm{FU}$ for $15 \mathrm{~h}$, a significant number of apoptotic cells were stained positive with Annexin V-FITC and negative with PI (bottom right quadrant). When 5-FU was increased to $5 \mathrm{mg} / \mathrm{ml}$, the number of positive annexin V-FITC and PI-stained cells (upper right quadrant) that showed advanced apoptosis was significantly increased. Data are presented as means \pm S.D. Two other independent experiments produced similar results.

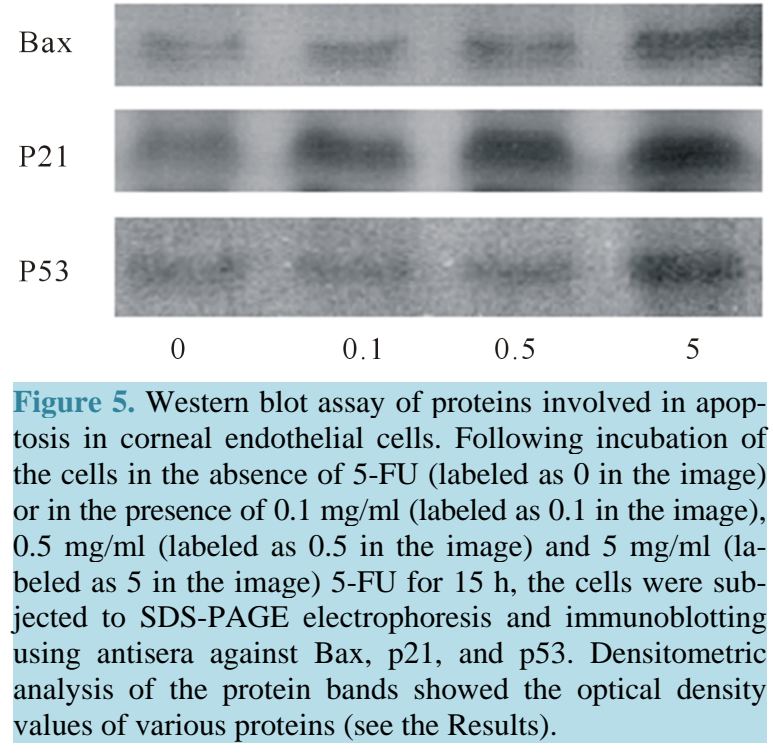

The apoptotic caspases induced by 5-FU is activated by two signal complexes: the extrinsic apoptosis pathway and the intrinsic apoptosis pathway. The extrinsic apoptosis pathway activates caspase 8 , in response to the 
ligation of cell surface death receptors. The intrinsic apoptosis pathway activates caspases 3 and 9 , in response to signals originating from mitochondria [18]. The intrinsic pathway relies on extrinsic signals to promote cell death in a cell- and tissue-dependent manner following DNA damage [20]. Evidence has shown that treatment with 5-FU increased the expression of Fas, which belongs to the death receptor pathway [21]. In normal thymus, 5-FU induced apoptosis is related to Fas, Bax, and caspase 3 coexpression [22]. Receptor binding results in activation of caspase 8, leading to activation of proapoptotic downstream molecules. Our data indicated that both caspase-8 and -9 inhibitors reversed the 5-FU-induced damage, suggesting that 5-FU-induced apoptosis in corneal endothelial cells may occur through both intrinsic mitochondria-mediated pathway and extrinsic pathway by death receptor. However, the 5-FU-induced extrinsic apoptosis pathway, in particular in corneal endothelial cells, needs to be explored deeply.

In the present study, we used porcine corneal cells to investigate the cellular toxic effect of 5-FU because porcine eyes are more similar to human eyes than the eyes of any other animal species [23]. In a previous study with bovine corneal endothelial cells assayed with Mosmann's colorimetric method, $50 \mathrm{mg} / \mathrm{ml}$ 5-FU exerted a clear toxic effect after exposure for $60 \mathrm{~min}$ [24]. In our study, such amount as low as $0.05 \mathrm{mg} / \mathrm{ml}$ 5-FU caused obvious damage to the mitochondria in corneal endothelial cells. The clinical dosage of 5-FU used for the management of early bleb failure varies according to the ophthalmologists. In clinical trabeculectomy, some patients received intraoperative subconjunctival local soaking with 5-FU (50 mg/ml for 4 to $5 \mathrm{~min}$ ) during surgery [25] [26]. However, others received repeated subconjunctival injections of 5-FU, with an initial dose of 2 to $5 \mathrm{mg} / \mathrm{ml}$ once daily and up to a total dose of $65 \mathrm{mg}$ [6] [19]. A recent study reported that even 0.0013 and $0.00013 \mathrm{mg} / \mathrm{ml}$ of 5-FU caused obvious damage to corneal endothelial cells, including actin disruption, changes in migrating cells which they did not display elongated processes typical of control tissues, and cellular translocation into the injury zone is retarded [27].

Studies have revealed that a single $5 \mathrm{~min}$ application of $25 \mathrm{mg} / \mathrm{ml}$ 5-FU induced cellular apoptosis in Tenon's fibroblasts [7]. Apoptosis characteristics were also reported in conjunctival epithelium after a subconjunctival injection of 5-FU, including dying conjunctival epithelium cells with nuclear apoptotic cell death [5]. Thus, at clinically high doses of repeated injections of 5-FU are highly likely to exert direct/indirect actions on corneal endothelial cells.

In hepatoma cells, 5-FU induced the up-regulation of Bax, p53, and p21 and triggered the collapse of the mitochondria membrane potential [28]. 5-FU also induced expression of the pro-apoptotic proteins (caspases-8, -9, -3, and Bax) in HeLa cervical carcinoma [29]. However, the mechanism of apoptosis induction by 5-FU in ocular tissue is poorly understood at present. Our data illustrate that 5-FU induced cellular DNA fragmentation and triggered apoptosis-related proteins, Bax, p21, and p53, in corneal endothelial cells. Under normal physiological conditions, p53 acts as a transcription factor, which participates in cell cycle checkpoint processes and apoptosis. It limits cellular proliferation after damage to genomic DNA through two alternative mechanisms: $G_{1}$ (or $G_{2}$ ) arrest; or apoptosis. In response to DNA-damaging agents, the p53-activated p21 protein which is an important downstream effector in the p53-specific growth arrest pathway [30]. Cell-cycle arrest and apoptosis induced by p53 protein were associated with upregulation of p21 and Bax proteins [31].

Based on the dose response of 5-FU in corneal endothelial cells, we found that disruption of the mitochondrial transmembrane potential was the first apoptotic step detected. The mitochondria then released the pro-apoptotic factors, such as cytochrome $c$, from the inner mitochondrial membrane into the cytosol, thereby activating the caspase-9 cascade. Thus, mitochondrial depolarization is an early event marker of more severe apoptotic events. In comparison with the MTT experiments shown in Figure 1(A), the mitochondrial depolarization can occur in the absence of cell death because exposure of the cells to $0.05 \mathrm{mg} / \mathrm{ml} \mathrm{5-FU}$ for $15 \mathrm{~h}$ did not cause significant toxicity in the MTT assay.

Utilization of annexin V-FITC/PI to identify the turnover of cell membrane phosphatidylserine in the presence of 5-FU indicated that only a small number of early apoptotic cells were clearly stained by annexin V-FITC after $15 \mathrm{~h}$ of incubation in 0.1 and $0.5 \mathrm{mg} / \mathrm{ml}$ 5-FU. They were stained positive for annexin V-FITC and negative for PI. Comparing the apoptotic dose response for mitochondria and DNA with that of the cell membrane suggests that, the cellular membrane appears to be the most resistant to 5-FU-induced damage.

It is not easy to detect drug-induced damage of corneal endothelial cells unless the side effects of 5-FU are severe enough to interfere with normal cellular physiological function. Many side effects of 5-FU may occur after a particular period of clinical use. The endothelial cell loss 7\% - 8\% has been reported with 5-FU after trabeculectomy compared with preoperative count [32]. However, counting cell numbers is not equal to cellular 
function. Thus, the cell count method alone is not suitable for estimating the toxic effect of 5-FU on corneal endothelial cell. Our data showed that the mitochondria of corneal endothelial cells are damaged in the presence of $0.05 \mathrm{mg} / \mathrm{ml} 5$-FU for $15 \mathrm{~h}$. The efficiency of corneal pump may be affected after a period of 5-FU use especially in cases of accidental access of 5-FU into the anterior chamber of eye and/or a reduction in the aqueous turnover rate.

\section{Conclusion}

In conclusion, 5-FU induced apoptosis in corneal endothelial cells occurs through activation of intrinsic mitochondrial and extrinsic caspase-8 apoptotic pathways, as well as by up-regulation of Bax, p21-, and p53-dependent signal transduction pathways. Although evidence suggests that 5-FU is less toxic than mitomycin-C to Tenon's fibroblasts, high dose 5-FU may result in the apoptosis of ocular cells [7]. The appearance of apoptotic characteristics in corneal endothelial cells may extend the chronic toxicity of 5-FU to cells. Thus, the use of 5-FU may also need to be carefully monitored for adverse changes in corneal endothelial cell.

\section{Acknowledgements}

This project was supported by the research grant from the Kaohsiung Municipal Ta-Tung Hospital (KMTTH99-009) and (KMTTH-100-001) and Kaohsiung Medical University (KMU-M097011) and (KMU-M098032).

\section{References}

[1] Camacho, L.H., Garcia, S., Panchal, A.M., Lim, J., Hong, D.S., Ng, C., Madoff, D.C., Fu, S., Gayed, I. and Kurzrock, R. (2010) Exploratory Study of Hepatic Arterial Infusion Oxaliplatin with Systemic 5-Fluorouracil/Bevacizumab in Patients with Refractory Solid Tumor and Extensive Liver Metastases. Clinical Colorectal Cancer, 9, 311-314. http://dx.doi.org/10.3816/CCC.2010.n.045

[2] Kareem, A.A., Farhood, Q.K. and Alhammami, H.A. (2012) The Use of Antimetabolites as Adjunctive Therapy in the Surgical Treatment of Pterygium. Clinical Ophthalmology, 6, 1849-1854. http://dx.doi.org/10.2147/OPTH.S38388

[3] Rashad, M.A. (2013) Efficacy of Repeated 5-Fluorouracil Needling for Failing and Failed Filtering Surgeries Based on Simple Gonioscopic Examination. Clinical Ophthalmology, 7, 15-22. http://dx.doi.org/10.2147/OPTH.S34848

[4] De Klerk, T.A., Chaudhry, N. and Moriarty, A.P. (2013) Enhanced Trabeculectomy in a UK District General Hospital Setting: Is Selective Use of 5-Fluorouracil All That Is Required? International Ophthalmology, 33, 447-451. http://dx.doi.org/10.1007/s10792-012-9712-4

[5] Simsek, T., Cankaya, A.B. and Elgin, U. (2012) Comparison of Needle Revision with Subconjunctival Bevacizumab and 5-Fluorouracil Injection of Failed Trabeculectomy Blebs. Journal of Ocular Pharmacology and Therapeutics, 28, 542-546. http://dx.doi.org/10.1089/jop.2012.0035

[6] Reinthal, E.K., Denk, P.O., Grub, M., Besch, D. and Bartz-Schmidt, K.U. (2007) Dose, Timing and Frequency of Subconjunctival 5-Fluorouracil Injections after Glaucoma Filtering Surgery. Graefe's Archives for Clinical and Experimental Ophthalmolog, 245, 369-375. http://dx.doi.org/10.1007/s00417-006-0406-3

[7] Crowston, J.G., Akbar, A.N., Constable, P.H., Occleston, N.L., Daniels, J.T. and Khaw, P.T. (1998) AntimetaboliteInduced Apoptosis in Tenon's Capsule Fibroblasts. Investigative Ophthalmology \& Visual Science, 39, 449-454.

[8] Lattanzio, F.A. Sheppard Jr., J.D., Allen Jr., R.C., Baynham, S., Samuel, P. and Samudre, S. (2005) Do Injections of 5-Fluorouracil after Trabeculectomy Have Toxic Effects on the Anterior Segment? Journal of Ocular Pharmacology and Therapeutics, 21, 223-235. http://dx.doi.org/10.1089/jop.2005.21.223

[9] Narula, P., Xu, M., Kuang, K.Y., Akiyama, R. and Fischbarg, J. (1992) Fluid Transport across Cultured Bovine Corneal Endothelial Cell Monolayers. Am J Physiol, 262, 98-103.

[10] Crawford, K.M., Ernst, S.A., Meyer, R.F. and MacCallum, D.K. (1995) NaK-ATPase Pump Sites in Cultured Bovine Corneal Endothelium of Varying Cell Density at Confluence. Investigative Ophthalmology \& Visual Science, 36, 13171326.

[11] Lv, X.G., Ji, M.Y., Dong, W.G., Lei, X.F., Liu, M., Guo, X.F., Wang, J. and Fang, C. (2012) EBP50 Gene Transfection Promotes 5-Fluorouracil-Induced Apoptosis in Gastric Cancer Cells through Bax- and Bcl-2-Triggered Mitochondrial Pathways. Molecular Medicine Reports, 5, 1220-1226. http://dx.doi.org/10.3892/mmr.2012.805

[12] Simsek, T., Firat, P., Citirik, M., Ozdamar, Y. and Elgin, U. (2010) Short-Term Effects of Subconjunctival Injections of 5-Fluorouracil on Conjunctival Epithelium. Cornea, 29, 727-731. http://dx.doi.org/10.1097/ICO.0b013e3181c38723

[13] Mohan, R.R., Liang, Q., Kim, W.J., Helena, M.C., Baerveldt, F. and Wilson, S.E. (1997) Apoptosis in the Cornea: 
Further Characterization of Fas/Fas Ligand System. Experimental Eye Research, 65, 575-589. http://dx.doi.org/10.1006/exer.1997.0371

[14] Wilson, S.E. and Kim, W.J. (1998) Keratocyte Apoptosis: Implications on Corneal Wound Healing, Tissue Organization, and Disease. Investigative Ophthalmology \& Visual Science, 39, 220-226.

[15] Wu, K.Y., Wang, H.Z. and Hong, S.J. (2008) Mechanism of Mitomycin-Induced Apoptosis in Cultured Corneal Endothelial Cells. Molecular Vision, 14, 1705-1712.

[16] Hong, S.J., Wu, K.Y., Wang, H.Z. and Lai, Y.H. (2001) Toxic Effects of Mitomycin-Con Cultured Ciliary Process Cells and Trabecular Meshwork Cells. Journal of Ocular Pharmacology and Therapeutics, 17, 331-342. http://dx.doi.org/10.1089/108076801753162744

[17] Wu, K.Y., Wang, H.Z. and Hong, S.J. (2005) Effect of Latanoprost on Cultured Porcinecorneal Keratocytes. Current Eye Research, 30, 871-879. http://dx.doi.org/10.1080/02713680591006237

[18] Liu, S., Wang, J., Niu, W., Liu, E., Wang, J., Peng, C., Lin, P., Wang, B., Khan, A.Q., Gao, H., Liang, B., Shahbaz, M. and Niu, J. (2013) The $\beta 6$-Integrin-ERK/MAP Kinase Pathway Contributes to Chemo Resistance in Colon Cancer. Cancer Letters, 328, 325-334. http://dx.doi.org/10.1016/j.canlet.2012.10.004

[19] Pakravan, M., Miraftabi, A., Yazdani, S., Koohestani, N. and Yaseri, M. (2011) Topical Mitomycin-C versus Subconjunctival 5-Fluorouracil for Management of Bleb Failure. Journal of Ophthalmic \& Vision Research, 6, 78-86.

[20] Kuribayashi, K., Finnberg, N., Jeffers, J.R., Zambetti, G.P. and E1-Deiry, W.S. (2011) The Relative Contribution of Pro-Apoptotic p53-Target Genes in the Triggering of Apoptosis Following DNA Damage in Vitro and in Vivo. Cell Cycle, 10, 2380-2389. http://dx.doi.org/10.4161/cc.10.14.16588

[21] Saleh, E.M., El-Awady, R.A. and Anis, N. (2013) Predictive Markers for the Response to 5-Fluorouracil Therapy in Cancer Cells: Constant-Field Gel Electrophoresis as a Tool for Prediction of Response to 5-Fluorouracil-Based Chemotherapy. Oncology Letters, 5, 321-327.

[22] Aquino Esperanza, J.A. Aguirre, M.V. Aispuru, G.R. Lettieri, C.N. Juaristi, J.A. Alvarez, M.A. and Brandan, N.C. (2008) In Vivo 5-Fluorouracil-Induced Apoptosis on Murine Thymocytes: Involvement of FAS, Bax and Caspase3. Cell Biology and Toxicology, 24, 411-422. http://dx.doi.org/10.1007/s10565-008-9056-Z

[23] Ju, C., Gao, L., Wu, X. and Pang, K. (2012) A Human Corneal Endothelium Equivalent Constructed with Acellular Porcine Corneal Matrix. Indian Journal of Medical Research, 135, 887-894.

[24] Nuyts, R.M., Pels, E. and Greve, E.L. (1992) The Effects of 5-Fluorouracil and Mitomycin C on the Corneal Endothelium. Current Eye Research, 11, 565-570.

[25] Jurkowska-Dudzinska, J., Kosior-Jarecka, E. and Zarnowski, T. (2012) Comparison of the Use of 5-Fluorouracil and Bevacizumab in Primary Trabeculectomy: Results at 1 Year. Issue Clinical \& Experimental Ophthalmology, 40, e135e142. http://dx.doi.org/10.1111/j.1442-9071.2011.02608.x

[26] Palanca-Capistrano, A.M., Hall, J., Cantor, L.B., Morgan, L., Hoop, J. and WuDunn, D. (2009) Long-Term Outcomes of Intraoperative 5-Fluorouracil versus Intraoperative Mitomycin C in Primary Trabeculectomy Surgery. Ophthalmology, 116, 185-190. http://dx.doi.org/10.1111/j.1442-9071.2011.02608.x

[27] Gordon, S.R., Climie, M. and Hitt, A.L. (2005) 5-Fluorouracil Interferes with Actin Organization, Stress Fiber Formation and Cell Migration in Corneal Endothelial Cells during Wound Repair along the Natural Basement Membrane. Cell Motility and the Cytoskeleton, 62, 244-258. http://dx.doi.org/10.1002/cm.20099

[28] Kang, S.J., Lee, Y.J., Kim, B.M., Kim, Y.J., Woo, H.D., Jeon, H.K. and Chung, H.W. (2008) Effect of Bupleuri Radix Extracts on the Toxicity of 5-Fluorouracil in HepG2 Hepatoma Cells and Normal Human Lymphocytes. Basic \& Clinical Pharmacology \& Toxicolog, 103, 305-313. http://dx.doi.org/10.1111/j.1742-7843.2008.00280.x

[29] Yim, E.K., Lee, K.H., Bae, J.S., Namkoong, S.E., Um, S.J. and Park, J.S. (2004) Proteomic Analysis of Antiproliferative Effects by Treatment of 5-Fluorouracil in Cervical Cancer Cells. DNA and Cell Biology, 23, 769-776. http://dx.doi.org/10.1089/dna.2004.23.769

[30] El-Deiry, W.S. (1998) Regulation of p53downstream Genes. Seminars in Cancer Biology, 8, 345-357. http://dx.doi.org/10.1006/scbi.1998.0097

[31] Roh, J.L., Kang, S.K. and Minn, I. (2011) p53-Reactivating Small Molecules Induce Apoptosis and Enhance Chemotherapeutic Cytotoxicity in Head and Neck Squamous Cell Carcinoma. Oral Oncology, 47, 8-15. http://dx.doi.org/10.1016/j.oraloncology.2010.10.011

[32] Dreyer, E.B., Chaturvedi, N. and Zurakowski, D. (1995) Effect of Mitomycin C and Fluorouracil-Supplemented Trabeculectomies on the Anterior Segment. Archives of Ophthalmology, 113, 578-580. http://dx.doi.org/10.1001/archopht.1995.01100050044028 